\title{
The Redemption of History:
}

\section{A Reading of \\ Geoffrey Hill's A Treatise of Civil Power}

Geoffrey Hill practises a kind of aesthetic austerity of style in A Treatise of Civil Power (2005/2007) that in the end must be reckoned a part of its meaning, its vision of the body politic, power, and culture. ${ }^{1}$ Three elements combine in this respect: difficulty (so called), the constraining or tamping down of the lyric voice, and subject-matter. In relation to Hill "difficulty" is a hoary trope, and should not be exaggerated here. A good number of the thirty-one poems present only a modest level of difficulty to the patient reader; however, others, such as "On Reading Milton and the English Revolution" and "A Précis or Memorandum of Civil Power," are challenging, and their challenge, a deliberate recalcitrance to easy-

\footnotetext{
${ }^{1}$ A Treatise of Civil Power exists in three versions: (1) the original limited-edition pamphlet, Clutag Press, Thame (2005); (2) the version published by Yale University Press in the US and Penguin in the UK (2007); and the version quoted here, in Geoffrey Hill, Broken Hierarchies: Poems 1952-2012, ed. Kenneth Haynes (Oxford: Oxford University Press, 2013): 557-601. The essential argument and vision of the collectionmy main concern-is the same in the different versions. (2) and (3) do not vary much: (3) shortens "On Reading Crowds and Power" to its first verse-paragraph, deleting the three other sections, and leaves out altogether "On Reading Burke on Empire, Liberty and Reform." When I refer to the latter, I use the Penguin text.
} 
going assimilation, is one element of what the volume as a whole is telling us. In a fallen world-and we will see how much Hill has to say about the Fall later-false communication rides easily on subtle and not so subtle lies, distortions, evasions, self-interests, and self-deceptions. The torque of a complex style, elision, sometimes contorted nuance and exactness, are ways of trying to take language back in the direction of an original honesty-which is not to say that there isn't a lot of aesthetic joy, fun even, buried deep down. There is, we might say, a kind of negotiation between this austerity and this joy, so that occasionally an exquisite lyric fullness breaks out even though much of the time Hill is writing what he has called elsewhere "treatise-poems." ${ }^{2}$ In a self-reflexive manner, within the volume, he speaks of writing "recitatives" rather than "arias," of his desire to "unmake / all wrought finalities, become a babbler / in the crowd's face," or, as he expresses it in another poem, to write "spare strophes that yield almost nothing / to the knowledge /outside them raw with late wisdom."3 As a philosophically learned poet, he is writing something like a treatise of politics and poetics which is prepared to live in the reader's mind not as some wholesome affirmation, but in a selfconscious brokenness, a symbolic enactment of the ever-recurring nature of human failure. His theological positions-putting a lot in a short space-are overwhelmingly orthodox, so that the self-emptying of God in

\footnotetext{
${ }^{2}$ Geoffrey Hill, "Civil Polity and the Confessing State," The Warwick Review 2, no. 2 (2008): 15 .

3 These quotations are from "Citations II," 1, 3, "Nachwort," 7-9, and "A Précis or Memorandum of Civil Power," 9-11.
} 
Christ lies at the heart of his religious understandings. 4 Moving forward into the aesthetic realm from these kinds of depth, we could say that what he is doing here is practising a deliberate ascesis of thought and word in relation to often tragic subject-matter.

\section{The Dilemma of History}

A Treatise's vision will remind many of Benjamin's image of the Angélus Novus looking back over the disaster of history-tyranny, war, repression, brutality, and dictatorship figure largely here-yet at the same time there are clear stirrings within this of Hill's religious position. Gillian Rose, the philosopher and late convert to Christianity, mourned here in the elegy "In Memoriam: Gillian Rose," is a clear influence on his perspective. Her work would provide a useful lens through which to grasp aspects of his religious position (though that is not my task here). One of Rowan Williams's paraphrases of Rose's views can take us quickly into the heart of the volume's concerns:

Talking about history is talking about the record or deposit of speech, in every possible sense, including very obviously the paradoxical speech of those silenced in history by the voices of others; the enterprise of reading history as intelligible, as generative of understanding and strategy now, is, it seems, the

\footnotetext{
4 See, for example, his "Poetics and the Kenotic Hymn," an appendix in Lucien Richard, Christ: The Self-Emptying of God (New York: Paulist Press, 1997): 195-97.
} 
unavoidable form of thinking about thinking, once we have understood that what we can say and think is empowered by what has been said and thought. This is ultimately to return us to Hegel's fundamental insight: history is how we do our metaphysics, how we reflect on what we non-negotiably are and what are the conditions of our concept-formation. Not that history as record delivers to us a map of the constructions of the universe, or a comprehensive account of natural kinds or a compelling thesis about the nature of reference; but engagement with history lays bare for us the character of thinking as engagement, as converse, conflict, negotiation, judgement and self-judgement.5

Hill-like Rose, and like Williams-emphasizes the vulnerability to error, self-deception, and failure of all our beliefs, projects, and actions within time, how they exist within a situation over which we do not have-could not have-complete control. Meaningful thought and action can only take place after we acknowledge, deeply, how we pre-exist within an always distorted situation, how our beliefs, and the actions resulting from them, involve the risk of error, that we may be misreading our situation, hence the situation of those who surround us-hence his wariness of any totalizing politics. The gist here is to see the (inevitable) violence implicit or explicit within different kinds of situation and that, within the

\footnotetext{
5 Rowan Williams, "Between politics and metaphysics: reflections in the wake of Gillian Rose," in Wrestling with Angels: Conversations in Modern Theology (London: SCM Press, 2007): 67.
} 
conditions of time, there is no way of side-stepping this reality; we have to work within it, via self-critique, negotiation, and (if needs be) suffering.

Six of the poems in the collection focus on the reign of Henry VIII and on the lives of Thomas Wyatt, Henry Howard, Earl of Surrey, and Hans Holbein: these are "Holbein I," "Holbein II," "Parallel Lives I," "Parallel Lives II," "In Framlingham Church," and "De Necessitate." The broad reading of Henry's reign these imply, particularly from the perspective of artists and poets, is that so well outlined in Greg Walker's Writing under Tyranny: English Literature and the Henrician Reformation (though dates of publication preclude direct influence). Walker's epigraph, from Maurice Latey's Tyranny: A Study in the Abuse of Power, could equally well be set over these poems: "Tyranny is, so to speak, a nervous breakdown of the body politic." 6 Amid the intensifying fractiousness of the 1530 ond 1540 os, Hill considers what was it like to be Thomas Wyatt (the conveyor of the sonnet form into English) seeing his friend Thomas Cromwell beheaded; or Henry, Earl of Surrey (the inventor of blank verse), watching his ideals of honour travestied by the king's policies, and himself eventually falling foul of royal paranoia; or the great portraitist, Hans Holbein, whose works appear so serene, painting in an atmosphere where it was perilously easy for former clients to lose their heads.

\footnotetext{
${ }^{6}$ Greg Walker, Writing under Tyranny: English Literature and the Henrician Reformation (Oxford: Oxford University Press, 2005), p. v.
} 
The unrhymed sonnet "Holbein II" celebrates the invention of blank verse by Henry Howard, Earl of Surrey, sometime in the early 1540 s (probably 1543). The discovery of this verse-form, eventually one of the crucial modes of English poetry, took place during his attempt to translate the Aeneid into English. For Hill, following the best scholarship here, but also in some sense going beyond it, the invention of blank verse was not a purely aesthetic matter, a discovery in the artistic realm; in fact-this is part of the wider meaning of the volume-it is the very idea of a "purely aesthetic matter" that is being contested. Surrey was resisting the moral and political framework within which he found himself by developing this dignified and flexible verse-form.

The great study of Surrey, which Hill certainly knows, is W. A. Sessions' Life, in particular chapter 10:

The young earl's language was intended specifically as discourse for a Tudor court, a language of nobility with the heightened conversation one might hear flowing at Surrey House, at Windsor, at Whitehall. It was written, then, at least on one level, with a specific political goal in mind, a renovatio of English blood nobility.... In the last decade of his life, the young earl had found a specifically English heroic line-deep within himself-for the objective representation of a history he did not fully understand but must encounter and confront. His line of ten unrhymed 
syllables will inscribe a narrative of Virgilian destiny: uncontrolled eros before an equally uncontrolled thanatos, history's constant tendency 'ruere in peius' ('to sink into the worse'), in the phrase from the Georgics (1:200), which Curtius sees as crucial to any interpretation of Virgil. ... Transferring the Roman epic into English would be one more way to bring order to the dislocation of his own time, another Roman role to control the 'frencey in our commyn wele', in Thomas Starkey's phrase.7

In "Holbein II" we have a modulated version of this thought:

Imagine Hercules mated with the Hydra, this king of bloody trunks their monster child. More would have so rated him the arch cleaver of women and old holy men. Cerebral incest, his sperm a witch broth. And Surrey, with his hierarchy of verse. Meticulous the apportioning of time in its reserve, Virgilian rectitude, as though a full pavane of the elect

${ }^{7}$ Henry Howard, the Poet Earl of Surrey: A Life (Oxford: Oxford University Press, 1999), 260, 262, 263-64. 
were the ten syllables to which they trod as to the noblest music in the land,...

We may at first be puzzled by "they" (10), but the context makes clear that it refers back to Thomas More in line 3, so that "they" is both Surrey and More, and by implication other resisters of the times. The pavane, "a grave and stately dance, in which the dancers were elaborately dressed" $(O E D)$, was indeed introduced into England from France during Henry's reign. The grace of pause and movement in blank verse at its best-as in Surrey's Aeneid-becomes an image for that sense of right hierarchy, timeliness, and "rectitude" embodied in the dance, all the qualities so lacking in the modes and manners of the exercise of civil power. The closing lines of this sonnet evoke the sparse, disciplined, but "lovely fecundity" (12) of the countryside around Framlingham, Suffolk, where Surrey is buried, as yet another parallel for the quietly understated but beautiful order of blank verse itself.

In miniature here we have one element of the larger theme of the collection, a theme already dealt with extensively in Hill's critical writings, particularly in The Enemy's Country (1991). That work was at pains to demystify the canon of poetry and prose, to make clear that the endeavour of real literary art rarely takes place in some luxurious vacuum away from contingent pressures. One of its epigraphs is from Ezra Pound: "You cannot call a man an artist until he shows himself 
capable of reticence and of restraint, until he shows himself in some degree master of the forces which beat upon him." ${ }^{8}$ This seems to be echoed in "Holbein II" by "reserve, Virgilian rectitude" (8). For Hill an attribute of the true artist is that he or she is morally braced against the times, whilst also deeply aware of the perils of self-deception. Here he seeks to disrupt some glamorous or distant reading of "the Tudors" by the company in which he sets Surrey. For convenience of simplification, I pick out Edmund Burke, William Blake, Ernst Barlach, and Aleksander Wat.

"On Reading Burke on Empire, Liberty, and Reform,"9 takes David Bromwich's selection from Burke's writings as an occasion for examining aspects of Burke's stance towards the American war, and how that stance was bound up with his "cogent style" (16). For Hill, of course also, prose style is not some aesthetic add-on, indeed style/meaning is more even than a binary. Involving manner, "technic," craftsmanship, style determines to a large extent what can possibly be said and perceived; it is a moral attribute. The phrases quoted in italics in this poem are from Burke's great speech attempting to divert England from the American war, "Mr Burke's Speech on Moving his Resolutions for Conciliation with the Colonies" (March 1775), which emerges out of a level of "culture" (22) lacking in the contemporary world. We are being asked to imagine a history that avoided the long brutalities of the American war, in which

\footnotetext{
8 Originally from Ezra Pound, Selected Prose 1909-1965 (New York: New Directions, 1973), 114.

9 See footnote 1.
} 
America-England might still be a political unit. As far as Hill is concerned Burke was prophetic in his opposition to the war, and it is hard not to think that contemporary parallels are in play.

The Burke poem leads us on to the poem about William Blake, "On Reading Blake: Prophet Against Empire," a response to David V. Erdman's seminal study, for it too has its starting-point in the American war. Most of the stanzas are simply following through, wittily, points made in Erdman's book: that Blake's early cynicism at the restoration of the political status quo after the disaster of the American war, as shown still active in the early skit An Island in the Moon (1784), was what converted into his spiritual notion of "innocence" (stanza 1); that Blake's crypticism in his works was a response to his fear of Britain's repressive government as it developed in the war years (stanza 2); that his painting The Spiritual Form of Nelson guiding Leviathan (1809) - which initially appears so heroic-is actually a subversive attack on Nelson as "heroic villain" and on the force of imperial power (stanza 3). Hill sympathizes with Blake in his long mental suffering during the years of the Napoleonic wars.

This can move us on to two more images of artist-as-moral-resister in the twentieth century. "In Memoriam: Ernest Barlach" celebrates the great sculptor for the way he was in touch with the Low German, earthy culture of his part of Germany, and for his great Ehrenmal (cenotaph) and Mahnmal (memorial) to the dead of the First World War. Hill emphasizes that with regard to Barlach "Artist Against the Third Reich" 
would be "something of a misnomer" (24-25), since, though he opposed the regime, his condemnation as a degenerate artist occurred mainly because of the way in which his profound, often tragic, images so completely failed to play to the new stridently positivist, nationalist agenda. "In Memoriam: Aleksander Wat" recalls the poet's death-note to his wife, "Do nothing to revive me" (4), after he had finally, close to death anyway, taken an overdose of sleeping pills to ease himself out of the years of pain and ill health that he had suffered as a consequence of Stalin's camps. Hill celebrates how Wat's surrealism was a subtle reaching above and beyond all he had suffered and seen, all the prisons, hospitals, forced deportations, and confinements of different kinds that he endured during the years 1941-1944.

Cumulatively, there is something terrible about bringing these and other instances of suffering together, a force of persuasion; other poems, for example, deal with the English Civil War, the German invasion of France in 1940, and the Warsaw Ghetto. In ranging across times we have something of the effect of the famous passage in Newman's Apologia, chapter 5 , where he maps out his reasons for believing in the Fall and original sin, a passage that has been a touchstone of Hill's wider thinking: "To consider the world in its length and breadth, its various history, the many races of man, their starts, their fortunes, their mutual alienation, their conflicts..." And so it goes, on and on, culminating in this: 
[to consider] the defeat of good, the success of evil, physical pain, mental anguish, the prevalence and intensity of sin, the pervading idolatries, the corruptions, the dreary hopeless irreligion ...-all this is a vision to dizzy and appal; and inflicts upon the mind the sense of a profound mystery, which is absolutely beyond human solution. ${ }^{10}$

The liberal or secularist critic has at least the duty to see where Hill is coming from, for as a poet he is surely marked out uniquely in our time by the profundity of his sense of original sin and its consequences. One danger here is simple confusion over this now less-than-familiar religious language. Since the poems above describe what they mean in this regard, perhaps the possibility of misunderstanding is reduced. Hill's vision of things goes backwards and forwards in time, with a sense, again and again, that humankind is self-alienated from its best desires and ends; for him a progressivist or Whig-liberal ascending trajectory to history is impossible. His implicit warning is that the political order of liberal societies is far more fragile than we suppose.

He is not making exact parallels-that is not the point. The tyranny of Henry VIII is not the same as Stalin's; the concentration camp in Russia where Aleksander Wat was held is not the same as the Tower of London in which Wyatt and Surrey suffered. Nonetheless, these things are being

10 John Henry Newman, Apologia Pro Vita Sua, ed. Martin J. Svaglic (Oxford: Clarendon Press, 1967), 217. Hill often cites Newman's characterization of the Fall as humankind's "terrible aboriginal calamity," a phrase occurring later in this passage. 
made to resonate together. Times may be different, he implies, but often they are differently the same. It is the Fall that makes the quest for the true disposition of civil power such an endless and endlessly crucial concern, given history's propensity "to sink into the worst."

\section{Against False Optimism}

There is one relatively minor poem in the volume that is particularly important as a means to understand the volume's larger argument: “After Reading Children of Albion (1969)." We may not notice at first the date in the title, but it is there to point us to the 1960s' high moment. The book referred to is Children of Albion: Poetry of the 'Underground' in Britain, edited by Michael Horovitz, an anthology of countercultural and protest poets, helping to forge, as they saw it, the new and better consciousness that would replace the world of late capitalism, with its wars, authoritarianism, and lack of love. In the anthology's "Afterwords" Horovitz describes his own moment of "conversion" in 1960s' Oxford, when he saw that "the mutual response between people determined to free their spirit can simultaneously give birth to the architecture of liberation." ${ }^{11}$ There follows an account of the "International Poetry Incarnation" at the Albert Hall (June 1965), and of other poetry events "intermingling and loosening the perimeter divisions between poetry-

${ }^{11}$ Michael Horovitz, Children of Albion: Poetry of the 'Underground' in Britain (Harmondsworth: Penguin, 1969), 321. Further references are in the text. 
jazz-blues-raga and modern classical music" (327). Poetry was released from the "dusty iambic grooves of book (society) culture" and the effects of "Eliot's cerebral intonations," and, "the margin between verse and song” being closed up, it became a living performance art once more:

Fellow feeling between poets plants an Eden of new consciousness: in Blakean image, the lion (energy) slays the monster of mental operations \& lies down with the lamb (spirit)to rise again, as one man-'to smite the land with the rod of his mouth'; or nurture it with wells of song. (335)

So, in Children of Albion itself, we have this kind of anti-war poetry:

O come love these fearful warring armies

\& plant tulips deep inside their guns.

Come ready armed with flowers, bibles, buddhas

\& protect each other with kindly thoughts.

Seek out each aggressor to invite him to

Smoke with you the magic weed of peace. (56-57) 
“After Reading Children of Albion (1969)" certainly constitutes a critique of all this, but, considering some of the excesses above, its tone is contained, muted even. The volume, says Hill, constitutes a "Timeexpired accusation" (1). The Children of Albion-the poets of the volume and the new age-are no doubt now "old men and women / compromised by the deeds they signed in Eden / forsaking dearth" (4-6). I take it that the last words here are an echo of Paradise Lost, the tender words that Adam remembers God speaking to him:

This Paradise I give thee, count it thine

To Till and keep, and of the Fruit to eate:

Of every Tree that in the Garden growes

Eate freely with glad heart; fear here no dearth

(8. 319-22)

In the second strophe Hill contrasts Will Kemp's Jig of 1599-the extraordinary “Nine Days' Wonder” when Shakespeare's fellow actor and morris-dance expert danced all the way from London to Norwich-with a modern ersatz hour-long re-enactment of the same, complete with the stage-effect of "a gold Albion uprearing” (12). The problem for the 1960s' poets, as he sees it, is that they simply signed up to live in their false Eden forsaking the real "dearth" of the fallen world. In Gillian Rose's 
terms their proposal is "to abolish the ethical, the givenness of constraint, the already that grounds any present act of will," which is essentially "an attempt to take us out of time." 12 The last strophe of the poem picks up a line from a particular poem in the anthology, from John James's "Bathampton Morrismen at the Rose \& Crown," as another instance of protest occurring at too superficial a level, with insufficient self-knowledge and self-critique. His stance is certainly no loose attack on the era of free love, pot, spontaneity, and psychedelic consciousness. It is grounded, again, in his sense of the recalcitrance of the world and of the human heart to easy possibilities of goodness. This vein of thinking can be seen operating in a number of poems in the collection.

There are, for example, those poems where he draws attention to the toughness of aspects of his own working-class heritage. "Coda," which anticipates the later collection Oraclau (2012), is about his greatgrandfather, Pryce Jukes (1826-1895), who moved from near Newtown, in central Wales, to the Black Country, in 1870, his trade of iron-puddling being both difficult and hazardous. Here Hill describes himself as "great grandson, and son, of defeated men, / in my childhood, that is" (34-35), and attributes his sometimes dark moods and turns of mind to aspects of this heritage. In "In Memoriam: Ernst Barlach" this background is at play again, when he compares Barlach's Low German and Low German cultural background to the "low" Black Country dialect which surrounded him in his own youth. It is a moving and touching cross-over, and brings

${ }^{12}$ Again, as paraphrased by Rowan Williams: 63. 
alive to the reader unfamiliar with Barlach's part of Germany something of its resonance. The most surprising poem in this vein is "On Reading The Essayes or Counsels, Civill and Morall," in other words Francis Bacon's famous essays (1625). That work was a normal part of the canon of seventeenth-century literature with which Hill grew up: the essays are usually considered masterpieces of prose, and much praised for their aphoristic, clipped but judicious Senecan style. A standard kind of praise of them goes like this:

The charm of Bacon's writings lies in his "wit," in the broad old sense of the word, in which it means intellect as well as expression. The sagacity of the underlying thought on which we rest when we apprehend the meaning of his words is as potent an element in our impression of delight as the aptness of the phrase and the ingenuity of the allusion. It is the style, as including both matter and manner, that is the man.13

Hill is having none of this:

So many had nothing; we have orchards sometimes ill-neighboured, and are driven

${ }^{13}$ English Prose: Selections with Critical Introductions, ed. Henry Craik, vol. 2 (New York: Macmillan, 1916), 9-10. 
to untimely harvest, simply to thwart thieves. (1-3)

Suddenly, in the sending up of that intrusive "we," Bacon is marked out as inhabiting the world of the upper echelons of Jacobean society, remote from the world of the poor. It is a context and mindset in which poverty "means chiefly / poverty of mind" (24-25). So often suspicious of the way lyricism in poetry can muffle, evade, or elide truth-telling, here Hill is wondering how the subtleties of Bacon's rhetoric, delicate balance and antithesis so finely honed, may just be such another distancing of reality. Exaggerated class division persists: "So many had, and have, nothing" (42). His own parents "never owned a house": "I . . wish I could keep resentment / out of my voice" $(49,53-55)$. In very personal terms a supposed masterpiece of the canon is being challenged and set at a distance.

A last poem on this theme, with again the 1960 s somewhere at the heart of it, is "On Looking Through 50 Jahre im Bild: Bundesrepublick Deutschland I [i.e. 50 Years in Pictures: Federal Republic of Germany].” There is nothing particularly difficult or complex here, the poem being, from one point of view, a straightforward account of looking through a coffee table book of photographs charting the fifty years of the post-war reconstruction. Yet at its heart are these lines about 1960s' radical politics and the conservative responses to it: 
The riots and demonstrations that now appear

like interludes, masques, or pageants, or students' rags;

the police water-cannon: you look for the film's director

but cannot find him.

$(6-9)$

The accumulation "like interludes, masques, or pageants, or students' rags" almost tips into satire, the implicit criticism and distancing being pressed on us. The poem ends, where Hill so often ends, with thoughts of the Holocaust, and the image of West German Chancellor Willy Brandt kneeling spontaneously at the Warsaw Ghetto Memorial, in a silent gesture of repentance and apology. This was in 1970, and Hill gives the date in the poem as a kind of rebuke to the 1960s' high-jinks he describes above. Deep aspects of his partly generational response to 1960s' radicalism are here in play.

So far, rather ruthlessly perhaps, we have seen a poet who believes, emphatically, in the Fall and original sin-humankind's radical disorientation-and who evinces, quite directly, a fair amount of scepticism about our ability to work against this condition of blindness. For Hill, we exist in a real, absolute double-bind: we know the world is wrong and wrongly constituted, that our politics and political organization are bad, and that we have the capacity, so easily, to head seriously into darkness (war, dictatorship, etc.). Equally clearly, we can envisage, we desire, a better world, "the realm of primal justice and 
accord" (128), as "A Précis or Memorandum of Civil Power" so beautifully expresses it. What does this aspiration mean? Does it always have to be frustrated?

It is perhaps surprising that the way out of this dilemma, from an orthodox Christian viewpoint-the redemptive death and resurrection of Christ-is not something Hill speaks about directly. We might say that it is a hidden or implied centre, the gracious $x$ that releases humankind from the fatal stasis outlined above. The volume's title, A Treatise of Civil Power, directs us to its focus on politics and history, the issues of social organization, authority, and justice, and-as we have seen-the role of art and artist within these things. I suspect that directly religious verse seemed out of place in this context.

On the other hand, in this same context, some of the things seen so far must be turned upside down. There is a frisson, for Hill, in looking at the worst for, somehow and mysteriously, the worst may imply its opposite. Henry, Earl of Surrey, William Blake, Aleksander Wat, Ernest Barlach all suffered in their times under different kinds of repression and tyranny, but they were all moral resisters: their examples point to the fact that this is not the real or appropriate state of human affairs. Post-war Germany may often have evaded the full force of the meaning of the Holocaust legacy, rejoicing in its "Economic Miracle," indulging a kind of makebelieve politics, but the gesture of Willy Brandt, actually kneeling spontaneously at the Ghetto memorial, shows there are ways in which we can get near to what is true or adequate, ways in which we can speak a 
kind of language-or silence-that is a precondition for genuine political transformation. In hinting at the totality of buried and hidden good that is already active in the world, that can be recouped by human beings against the odds, Hill writes three poems focused on particular musical compositions. In complex and implicit ways, music is being used as an analogy for the quest for justice and peace in more material terms.

\section{The Quest for True Harmony}

To speak of the "political" role of music is clearly to enter a complex space. What are the viable or meaningful connections here? The question becomes all the more pressing, I think, once we realize that in speaking of "music" Hill is in part speaking of his own art of poetry. What is the real political role of art, if it is to be something truer, for example, than the poetry of the "children of Albion"? In one of his more fragmentary essays, Hill has been open about the dilemmas of trying to answer this question: "I have affirmed my belief that "poetry is inextricably bound into the purpose and function of civil polity'. I have also conceded my incapacity to suggest how any real 'purchase' (a Burkean word) of poetry on polity might be achieved."14 Neither does A Treatise supply any simple or downright answer. I suggest, however, that it does give an implied answer, which is worth heeding.

14 "Civil Polity and the Confessing State": 10. 
Hill takes for granted-or perhaps hopes to take for granted-readers' own experience of being profoundly moved by music and hence (as he would see it) of being opened up to the existential depths in which religious mystery can touch us. In A Treatise, in simple terms, music becomes a way of talking about our aspiration towards harmony and peace, the fundamental need for a pattern and shape in which all discord can be resolved or at least better managed or held within appropriate limits. Musical beauty is built up of its own internal resolutions of harmony and dissonance within a pattern of some kind of aesthetic image of order: to say this much is already to hint at how it might be said to image the good political state. Music's high beauty is for Hill an enacting of our aspiration towards the transcendentally other, a pointer to that unseen beauty from which the earthly order desperately needs to take its cue.

The first of the music poems is the most modest, for it deals essentially with harmony and dissonance within the individual life. "Johannes Brahms, Opus 2" evokes the second piano sonata in F-sharp minor, its hard fortissimo passages set sharply against passages of great tenderness. "Do not compound arrival with destiny / though here you could act so and be right" (8-9): in the individual life, lived with its highs and lows, its difficulties and elations, its sin and its goodness, we cannot see how "discord in harmony" (3) will be able to make some kind of sense in the end; the work of music is perhaps, by contrast with the moral realm, a kind of sleight of hand, where melodies, harmonies, and 
dissonances come to their proper end, and, in the case of Brahms, are bound to end in a resolution that makes sense of what has gone before. The danger for the individual life, of course, is that this might not happen. The poem's second half is more optimistic, or perhaps just more brusque: in the end, as the piece of music ends, so we too come to death, "the body of our endurance / over and done with" (6-7), and, whether we are religiously minded or not, there then is the pattern of our life shaped in time.

The next music poem is a little wider in its concerns. In the baldly named "G. F. Handel, Opus 6" we are being directed towards the Concerti Grossi or Twelve Grand Concertos (pub. 1739), primarily beautiful, controlled, but often very buoyant music for strings. Here the music provides a metaphor for good political organization and, further, and relatedly, a metaphor for the harmony of the poet's own marriage. The opening lines are a direct pointer to an intertextual link: "Monumentality and bidding: words / neither yours nor mine, but like his music" (1-2). The reference is to Hopkins's letters, via his own essay “Alienated Majesty: Gerard M. Hopkins":

In principle again, such a combination [of the 'robustious' and the 'very highly wrought'] could, in Hopkins's case, relate closely to one of his sharpest creative realizations: the relation of 'monumentality' to 'bidding'. 'Bidding' is Hopkins's term for 'the 
art or virtue of saying everything right to or at the hearer... and of discarding everything that does not bid, does not tell'. Hopkins goes on to make one of his most penetrating observations: 'It is most difficult to combine this bidding, such a fugitive thing, with a monumental style'. It is the key to what is right and wrong in his own poetic method; to what is strong and weak in Keats's poems of 1819-20 ('To Autumn', the unfinished 'Hyperion'); and to what, in Wordsworth or Tennyson, strikes us as noble simplicity rather than mere verbosity or canting. . . The genius of Hopkins's own late poetry-'That Nature is a Heraclitean Fire and of the comfort of the Resurrection', 'Thou art indeed just, Lord . . .'-is itself a structural compounding of bidding with monumentality: 'Mine, $\mathrm{O}$ thou lord of life, send my roots rain'. 15

In Handel's music there is a balance between "monumentality" and "bidding," between strength and the grace that tells, which come together in an image of that ideal interacting of "power" and "civility" (11) that would make up the ideally functioning state. This is then an image of the way in which eros and philia (friendship) make up the "composure" (16) of the poet's own relationship, its harmony being in its own way an image of the larger harmony that might, ideally, exist between all citizens in their relations with each other.

15 Geoffrey Hill, Collected Critical Writings, ed. Kenneth Haynes (Oxford: Oxford University Press, 2008), 529. 
The last music poem, or at least the last poem with music at its centre, though it is even more ranging in its concerns, is "A Précis or Memorandum of Civil Power." This is probably the finest poem in the volume, and certainly the most reaching in its ambition. I do not want to provide a line-by-line paraphrase, complex as it is, but rather to seek out a few crucial or essential elements of its meaning. "A Précis ..." has seven sections, the six days of creation and the day of rest being a number of harmony and hence a part of the quest for "the realm of primal justice and accord" (128). The poem begins and ends with thoughts about Olivier Messiaen's Quatour pour la Fin du Temps, the modernist quartet, for violin, clarinet, cello, and piano, composed while Messiaen was being held as a prisoner-of-war in a German prison camp after the defeat of France in 1940. Looking back over the subject-matter outlined above, it should be apparent how, in this one poem, Hill brings together the main concerns of the collection. Quatour pour la Fin du Temps was first performed in the prison camp by Messiaen and fellow prisoners, in January 1941, one of the masterpieces of twentieth-century music having its première-the word seems ludicrous in the context-in the appalling cold and privation of Stalag VIII-A. The event brings together the highs and lows of the twentieth century, the highs and lows of the human condition.

Appropriate to the French subject-matter, Hill starts the poem with a thought from "G. Marcel" (5), i.e. Gabriel Marcel (1889-1973), the French existentialist philosopher. Though Hill alludes to this passage 
from Etre et avoir in a thoroughly truncated form (4-5), it is the bedrock of the poem's thought, hence worth giving in full:

In turning my attention to what one usually thinks of as ontological problems, such as Does Being exist? What is Being? etc., I came to observe that I cannot think about these problems without seeing a new gulf open beneath by feet, namely, This I, I who ask questions about being, can I be sure that I exist? What qualifications have I for pursuing these inquiries? ... In spite of the thought which comes first into my head, I do not think that Descartes' cogito can be of any help to us here. The cogito, as I have written elsewhere, is at the mere threshold of validity; the subject of the cogito is the epistemological subject. Cartesianism implies a severance, which may be fatal anyhow, between intellect and life; its result is a depreciation of the one, and an exaltation of the other, both arbitrary. There is here an inevitable rhythm only too familiar to us, for which we are bound to find an explanation. It would certainly not be proper to deny the legitimacy of making distinctions of order within the unity of a living subject, who thinks and strives to think of himself. But the ontological problem can only arise beyond such distinctions, and for the living being grasped in his full unity and variety. ${ }^{16}$

${ }^{16}$ Gabriel Marcel, Being and Having, trans. Katherine Farrer (Westminster: Dacre Press, 1949), 170-71. 
For Hill nothing less than a sense of the mystery of Being, going far beyond the empirical, far beyond materialistic explanations, can account for the austere beauty of Messiaen's music composed in such times and under such conditions. From herein the argument of the rest of poem is not so hard to seek.

In section II, Hill thinks of the very young poet, John Cornford (19151936), a passionate communist, killed fighting in the Spanish Civil War, and of his fine poem "Heart of the Heartless World." The thought here is that Cornford was a genuinely impressive figure, and a potentially fine poet, but, from Hill's political viewpoint, he was getting things wrong. This is not some quick or trivial critique, along the lines of "a Communist is always wrong." In terms of moral action and choice all of us have to take a stance, and in so doing risk our own imperception and failure. The conditions within which we exist makes it hard to get things right. Section IV rehearses a version of this same thought: our own individual actions do "make history; it's not some / abysmal power" (69-70), and in that sense human order, because not instinctively graceful and strong like nature, is so much harder to get to work properly. Section V is a direct attack on the mendacities and inadequacies of the present functioning of the state in Britain. Section VII comes round again to the thought of Messiaen's quartet, now set explicitly in the context of France's "Strange Defeat" (135) in 1940, the reasons for this, and the "sick decorum of betrayal" (140) of the Vichy regime. 
Now Hill asks the question that may seem meaningless or hard of answer, the question that he assumes has occurred to the reader:

Why Quatuor pour la Fin du Temps, this has nothing to do surely with civil power? $(129-31)$

Surely, in the end, the aesthetic realm has nothing to do with the political organization and right disposition of the state, with politics in its most fundamental sense? What can Messiaen's art, and implicitly Hill's own art, have to do with the quest for true social and political organization, the kind that gives us justice and peace? There are two answers here, I suggest, though neither is going to be satisfactory to many readers.

One answer is given in quite bare and perhaps overly abbreviated terms in section VII itself. Messiaen's music, based on Revelations chapter 10, "strikes chords / direct and angular" (131-2) because it speaks of Eternity, of God's love beyond time, and so passes a kind of judgement on the 1930s' moral malaise of France which made it so vulnerable to German attack and on the deplorable circumstances of its own composition. It strikes up "irregular beauties contra the New Order" (147). "Irregular," in the context of Nazism, is weighted: the modernist element in Messiaen's treatment of tempo and harmony becomes a form 
of resistance in itself. "New Order" clearly means Nazism, but also the condition of existential Disorder generally.

A second answer, I suggest, comes via the poem's larger force-field, and indeed the whole volume. The practice of this kind of art embodies, makes audible as it were, a way of being whose spiritual resonances enact that human integrity which would solve all problems, which would lead us, individually and collectively-if all of us were so true to our best selves-to the "realm of primal justice and accord." There are other poems in the volume, which cannot be covered here, which point in this same direction: "Integer Vitae," for example, or "In Memoriam: Gillian Rose." The artist is not directly a saint-such a proposition would be absurd to Hill-but the vocation of art, if practised wholly and truly, is a means by which the integrity of the artist's practice manifested in real art becomes a symbol of truer ways of being. Here Hill's affinities within the English poetic tradition are writ large. His forebears are Herbert, Vaughan, Blake, and Hopkins, very different poets from one point of view, but all poets for whom their own religious lives and commitments were inseparable from the practice and meaning of their art. This is ultimately why, in A Treatise of Civil Power, Olivier Messiaen is the high-point of its symbolic pattern. Every Sunday in Stalag VIII-A, Messiaen, devout Catholic, secluded himself in prayer. The rest of the time, under privileges from the cultured German prison commandant, he composed his extraordinary music. 
This is a pre-copyedited, author-produced version of an article accepted for publication in Literary Imagination following peer review. The version of record Hawlin, S 2014, 'The Redemption of History: A Reading of Geoffrey Hill's A Treatise of Civil Power' is available online at: https://academic.oup.com/litimag/article-abstract/16/2/219/2751032 or doi:10.1093/litimag/imu010 . 